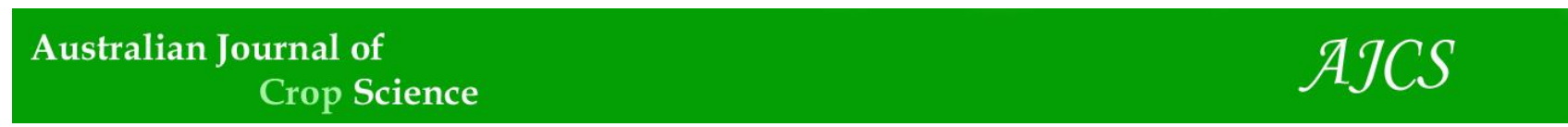

AJCS 12(06):892-897 (2018)

ISSN:1835-2707

doi: $10.21475 /$ ajcs.18.12.06.PNE846

\title{
Soybean yield performance associated with seed size, type of fertilizers and furrow openers
}

\author{
Maicon Sgarbossa'*, Jean Carlo Possenti' ${ }^{2}$, Carlos André Bahry², Alcir José Modolo'
}

'Postgraduate Program in Agronomy, Federal University of Technology - Paraná (Universidade Tecnológica Federal do Paraná - PPGAG/UTFPR), Pato Branco - PR, Brazil

${ }^{2}$ Department of Agronomy, Federal University of Technology - Paraná (Universidade Tecnológica Federal do Paraná - UTFPR), Dois Vizinhos - PR, Brazil

\section{* Corresponding author: maicon_sgarbossa@hotmail.com}

\begin{abstract}
There is some doubt about the influence of seed size among soybean producers, who often believe that larger seeds produce more vigorous plants. There is also some debate regarding the furrow opener, as it influences the depth of the fertilizer in relation to the seed. This study aimed to evaluate seeding parameters and the development and productivity of the soybean in regard to seed size and employing fertilizer furrow opener. The experiment was conducted in a typical distroferric red nitisol with very clayey texture in two crop seasons $2014 / 2015$ and 2015/2016. The experiment adopted a randomized block design in a factorial structure, with five replications. Treatments consisted of the combination of two seed sizes of Nidera NS 4823 RR cultivar (large $-6.5 \mathrm{~mm}$, and small - $5.5 \mathrm{~mm}$ in diameter) and two types of furrow opener (shank and double disc). The use of shank-type furrower resulted in a greater mobilized area and a greater sowing depth in both seasons. Due to environmental conditions, smaller seeds resulted in lower plants, 30 days after sowing and fewer pods per plant in the first studied season. In turn, seeds with larger diameter resulted in higher productivity in the second season, although in the first year there was no significant difference.
\end{abstract}

Keywords: Fertilizer depth; glycine max; grains; population of plants; productivity; seed drill; yield components.

Abbreviations: PS_seed deposition depth; AM_mobilized soil area; IVE_emergence speed index; DAS_days after sowing; GL_degrees of freedom; CV_coefficient of variation; AP_plant height; Colh_harvest; Pop_population; NVP_number of pods per plant; NGV_number of grains per pod; MMG_thousand grain mass; Prod_productivity.

\section{Introduction}

Using good quality seeds is essential to achieving high productivity in soybean crops. Seeds should have high germination rate and vigor, as these factors influence the speed, percentage and uniformity of seedling emergence in the field. Thus, a crop may present different populations of plants under field conditions, favoring those from larger seeds (Barbosa et al., 2010). However, smaller seeds can provide savings at the time of sowing, due to their higher yield (Andrade et al., 1997). Crop performance is also influenced by the quality of the planting furrow, which should be opened in such a way to ensure correct fertilizer and seed position and proper plant development (Aratani et al., 2006). Improper fertilizer deposition allows salts to come into direct contact with seeds, causing problems during germination, due to the saline effect (Moterle et al., 2009). A key factor in the emergence of the seed is the depth, at which it is deposited in the furrow. If said depth is greater than necessary for emergence, the seedling will take longer to emerge, remaining exposed to the attack of present pests in the soil. Excessive depth may even impair germination (Koakoski et al., 2007).

Reduction in plant population frequently occurs as a result of inadequate germination performance of seeds subjected to adverse conditions, which are often not properly evaluated by farmers (Vazquez et al., 2008). Slow emergence of plants may lead to population failure, developmental delays and weed control problems, besides of interference in plant characteristics related to harvesting, such as plant height, stem diameter and insertion height of the first pods (Marcos Filho, 2013). Smaller soybean seeds produce lower plants at harvest time and have lower productivity than larger seeds (Padua et al., 2010). In this context, this study aimed to evaluate seeding quality parameters, the development and productivity of soy plants linked to seeds with two different sizes and to use different fertilizer furrow openers.

\section{Results and discussion}

\section{Plantability parameters and plant development}

The sowing depth and mobilized soil area showed no significant differences on seed size during the two evaluated seasons. The type of furrow opener, on the other hand, influenced all parameters (Table 1). Regardless of the crop season, the shank-type furrower provided greater depth of seed deposition and greater mobilized soil area than the disc-type. It is desirable that the furrow openers are able to 
break the surface layer of the compacted soil, albeit with minimal soil movement, to avoid the incidence of invasive plants, as well as preventing erosion (Reis et al., 2006). Koakoski et al. (2007) also found that deeper seeding was ocurred using shank-type furrower, when assessing the performance of shank and double disc furrow openers on a seeder-fertilizer machine in soybean cultivation. However, Reis et al. (2006) reported opposite results, in which they justified that double disc may provide greater stability of the walls of planting furrows. Regarding mobilized soil area, Francetto et al. (2015) also observed higher values for the shank, with a $31.25 \%$ higher mean than the disc opener. The authors attributed this finding to the greater working depth of the shank, the differential action between the mechanisms for opening the furrow and the difference between the dimensional characteristics of the elements that interfere in the shearing, shear stress and compression they cause in the soil. Levien et al. (2011) also observed that shank caused $52 \%$ greater soil mobilization in the planting furrow, than that caused by the use of double disc. For the 2014/2015 crop season, the best emergence speed indexes were observed when the shank-type furrow opener was used (Table 2). This fact can be explained by the lack of moisture in the soil after sowing. The first rain $(20 \mathrm{~mm})$ was occurred only on the seventh day after sowing (Fig 1A). Thus, seeds deposited at greater depth (shank $=6.24 \mathrm{~cm}$ ), where they were able to emerge using the available moisture in the soil. In turn, seeds closer to the surface and fertilizer (disk $=4.52 \mathrm{~cm}$ ) took longer to emerge, as there was not enough moisture to begin the germination process. It is known that more rapid emergence is extremely positive, even in water stress situations, as it facilitates the control of weeds, which generally start their competition from establishment of the crop. According to Morando et al. (2014), the soy seed needs to absorb water at least $50 \%$ of its weight to ensure good germination.

Seedlings with higher emergence speed index present better performance and; thus, greater ability to withstand stresses that might interfere with the growth and development of the plant (Dan et al., 2010).

With respect to seed size, it was found that the highest IVE was obtained employing shank and the smaller diameter seed. This disagrees with the conclusions of Pereira et al. (2013) who stated that soybean seeds of a larger size germinate faster under optimum conditions of humidity. In the 2015/2016 crop season, IVE values were higher when the disc-type furrow opener was used (Table 1). This fact can be explained by the occurrence of rainfall $(28 \mathrm{~mm})$ two days after sowing (Fig 1B); thus, the seeds that were seeded at a lower depth (disc $=4.01 \mathrm{~cm}$ ) quickly absorbed water, emerging before those seeded at greater depth (shank = $5.29 \mathrm{~cm}$ ). In addition, as precipitation occurred immediately after sowing, it solubilized the fertilizer and neutralized the risk of saline damage, which is inherent to the fertilizer being closer to the seeds when using disc-type furrow opener. No significant differences in emergence speed were observed with regard to seed size.

\section{Performance and productivity components}

In the 2014/2015 season, the use of double disc provided lower plant height 30 days after sowing. However, in the 2015/2016 season the opposite was occurred, whereas shank providing lower plant heights (Table 3 ). These results may be related to the reasons discussed regarding delayed emergence, by which they negatively impacted the initial establishment of the crop. However, the height of the plants at harvest time showed no significant differences between the different types of treatments, demonstrating the ability of the crop to compensate initial differences.

Padua et al. (2010) evaluated the influence of soy seed size $(4.0,5.0$ and $6.0 \mathrm{~mm}$ sieves) in three cultivars and observed that the height of plants at harvest was similar, when seeds of 5.0 and $6.0 \mathrm{~mm}$ sieves were used. However, they observed a reduction in plant height when smaller seeds (4.0 $\mathrm{mm}$ ) were usied. The authors believe that the larger seeds usually have higher amount of reserve, playing an important role in crop establishment and yield under unfavorable environmental conditions.

In the $2014 / 2015$ season, there was significant interaction between seed size and furrower type for the plant population at 30 DAS and at harvest (Table 4). In the $2015 / 2016$ season, the plant population showed no significant differences at any time (Table 5). This result might be explained by the fact that rain occurred two days after sowing (Fig 1B).

Table 5 shows the mean population of plants, 30 days after sowing and at harvest for the 2014/2015 season. The lack of rain in the post-sowing period hindered the final stand, which reached between 42.8 and $69.2 \%$ of the expected population. It was also observed that the largest population of plants was obtained using the shank-type furrow opener and smaller seeds. This can be explained by the greater seeding depth provided by this furrow opener (Table 1), reaching a soil layer with higher water content at the time of sowing, favoring germination and initial plant stand, besides granting more distance between fertilizer and seeds.

The largest number of pods per plant was obtained using disc-type furrow opener with the largest seed, in the 2014/2015 crop season (Table 6) in the smallest plant stand condition. Under this condition, soybean has greater plasticity, such that there is more branching in the plants and; therefore, a larger number of pods per plant. Similar results were obtained by Tourino et al. (2002), when working with soybean crops with two distances between furrow lines (45 to $60 \mathrm{~cm}$ ) and five densities of plants in planting furrows $\left(10,13,16,19\right.$ and 22 plants $\left.\mathrm{m}^{-1}\right)$. The authors observed that the number of pods per plant varied significantly with the distance between lines, due to the larger emission of lateral branches by the plants. On the other hand, a higher number of pods were observed in 2015/2016 season, using the shank-type furrow opener. There were no significant differences in the number of grains per pod between treatments. Camozzato et al. (2009) found results similar to those in this study when evaluated three soybean cultivars (NK 8350, VMAX and CD 214 RR) and two seed sizes (small $-5.5 \mathrm{~mm}$, and large $-6.5 \mathrm{~mm}$ ). There was no significant difference in the thousand grain weight of $2014 / 2015$ season, between furrow openers and seed sizes. On the other hand, mean productivity values (Table 7), showed lower productivity, using the disc-type furrow opener in the first season of the experiment, which may be explained by the lower plant population (Table 4). In the second season, productivity was higher using the shank-type 
Table 1. Mean values and summary of ANOVA for seed deposition depth (PS), mobilized soil area (AM) and emergence speed index (IVE), crop season 2014/2015; seed deposition depth (PS), mobilized soil area (AM) and emergence speed index (IVE), crop seas on 2015/2016, according to furrow opener types and seed sizes.

\begin{tabular}{|c|c|c|c|c|c|c|c|}
\hline \multirow[t]{2}{*}{ Treatments } & & $\begin{array}{c}\text { PS } \\
(\mathrm{cm})\end{array}$ & $\begin{array}{c}\mathrm{AM} \\
\left(\mathrm{cm}^{2}\right)\end{array}$ & IVE & $\begin{array}{c}\text { PS } \\
(\mathrm{cm})\end{array}$ & $\begin{array}{c}\text { AM } \\
\left(\mathrm{cm}^{2}\right)\end{array}$ & IVE \\
\hline & & \multicolumn{3}{|c|}{$2014 / 2015$} & \multicolumn{3}{|c|}{$2015 / 2016$} \\
\hline \multicolumn{8}{|l|}{ Furrowers } \\
\hline Disc & & $4.52 \mathrm{~b}$ & $61.08 \mathrm{~b}$ & 8.39 & $4.01 \mathrm{~b}$ & $45.31 \mathrm{~b}$ & $38.41 \mathrm{a}$ \\
\hline Shank & & $6.24 \mathrm{a}$ & $98.06 \mathrm{a}$ & 17.00 & $5.29 \mathrm{a}$ & $102.71 \mathrm{a}$ & $28.81 \mathrm{~b}$ \\
\hline \multicolumn{8}{|l|}{ Seed size $(\mathrm{mm})$} \\
\hline 5.5 & & $5.22 \mathrm{a}$ & $80.38 \mathrm{a}$ & 14.23 & $4.56 \mathrm{a}$ & $71.71 \mathrm{a}$ & $33.66 \mathrm{a}$ \\
\hline 6.5 & & $5.54 \mathrm{a}$ & $78.76 \mathrm{a}$ & 11.16 & $4.74 \mathrm{a}$ & $76.31 \mathrm{a}$ & 33.57 a \\
\hline Factor & GL & \multicolumn{6}{|c|}{ Medium square } \\
\hline Blocks & 4 & & & & & & \\
\hline Furrowers (F) & 1 & $14.79 * *$ & $6835.38 * *$ & $370.48^{* *}$ & $8.19 * *$ & $16470.93^{* *}$ & $460.32 * *$ \\
\hline Seed size (S) & 1 & $0.51^{\mathrm{ns}}$ & $13.18^{\text {ns }}$ & $47.12 * *$ & $0.16^{\mathrm{ns}}$ & $105.57^{\text {ns }}$ & $0.04^{\mathrm{ns}}$ \\
\hline $\mathrm{F} \times \mathrm{S}$ & 1 & $1.02^{\mathrm{ns}}$ & $0.42^{\mathrm{ns}}$ & $27.89 * *$ & $0.12^{\mathrm{ns}}$ & $276.24^{\mathrm{ns}}$ & $4.77^{\mathrm{ns}}$ \\
\hline Residue & 12 & & & & & & \\
\hline CV (\%) & & 14.9 & 11.3 & 8.8 & 8.9 & 19.9 & 7.7 \\
\hline
\end{tabular}
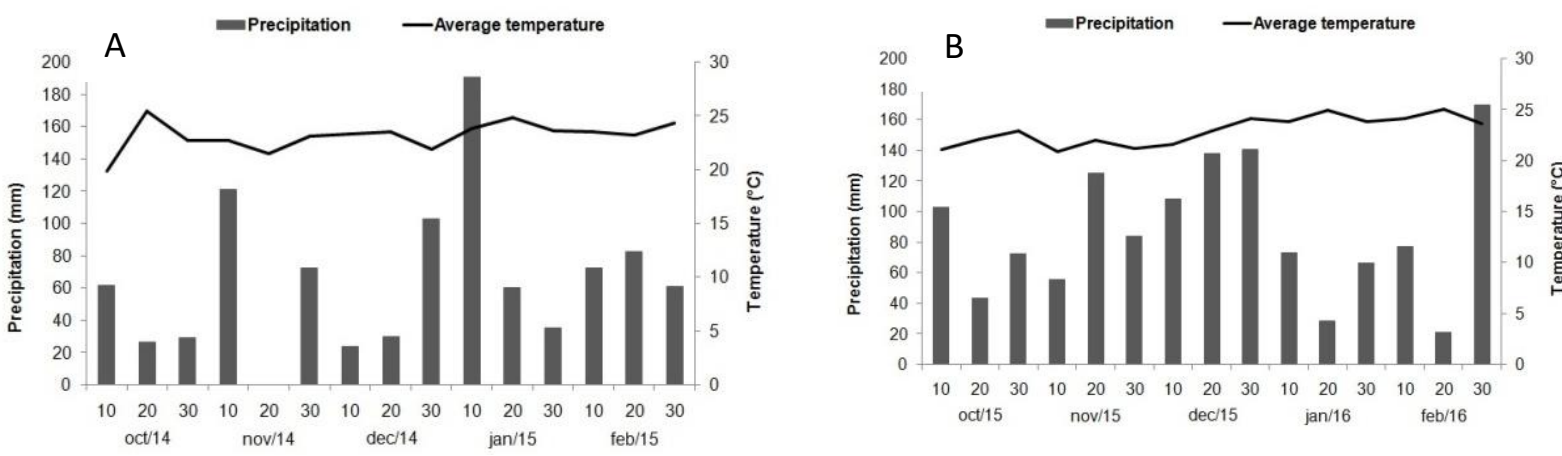

Fig 1. Meteorological data observed during the experimental period: A) crop season 2014/2015 and, B) crop season 2015/2016 Source: Agronomy Institute of Paraná (Instituto Agronômico do Paraná - IAPAR, 2016).

Table 2. Mean values of the emergence speed index (IVE) of the soybean, according to furrower type and seed size, crop season 2014/2015.

\begin{tabular}{lcc}
\hline & \multicolumn{2}{c}{ IVE } \\
\cline { 2 - 3 } Furrowers & \multicolumn{3}{c}{ Seed size $(\mathrm{mm})$} \\
\cline { 2 - 3 } & 5.5 & 6.5 \\
\hline Disc & $8.75 \mathrm{Ab}$ & $8.04 \mathrm{Ab}$ \\
Shank & $19.72 \mathrm{Aa}$ & $14.29 \mathrm{Ba}$ \\
\hline CV (\%) & & 8.8 \\
\hline
\end{tabular}

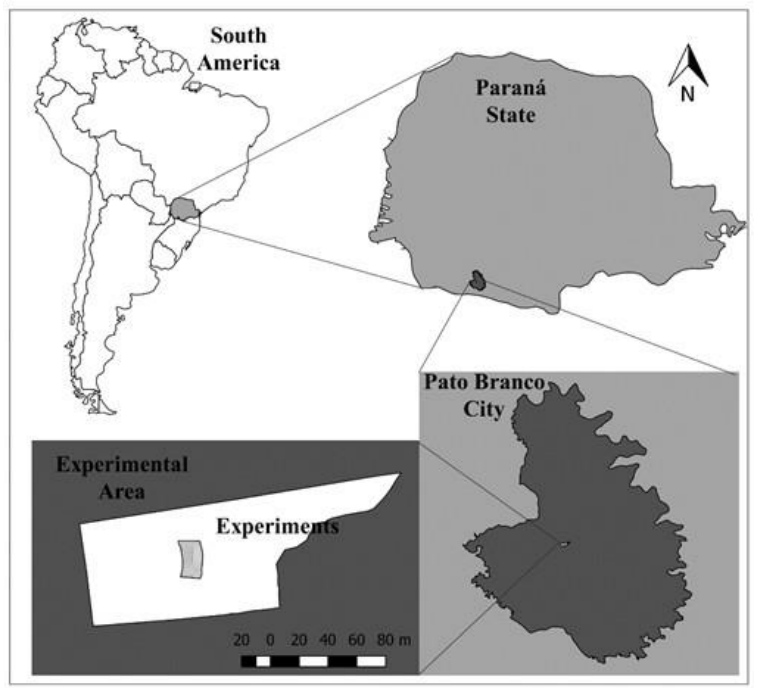

Fig 2. Geographical location of the study area. 
Table 3. Mean values and summary of ANOVA of plant height, 30 days after sowing (AP 30 DAS) and at harvest time (AP Colh), according to furrow opener types and seed sizes, crop seasons 2014/2015 and 2015/2016.

\begin{tabular}{|c|c|c|c|c|c|}
\hline \multirow{3}{*}{ Treatments } & & AP 30 DA & AP Colh & AP 30 DAS & AP Colh \\
\hline & & \multicolumn{2}{|c|}{$(\mathrm{cm})$} & \multicolumn{2}{|c|}{$(\mathrm{cm})$} \\
\hline & & \multicolumn{2}{|c|}{$2014 / 2015$} & \multicolumn{2}{|c|}{$2015 / 2016$} \\
\hline \multicolumn{6}{|l|}{ Furrowers } \\
\hline Disc & & $9.99 \mathrm{~b}$ & $77.27 a$ & $18.38 \mathrm{a}$ & $61.99 \mathrm{a}$ \\
\hline Shank & & $11.69 \mathrm{a}$ & $78.36 \mathrm{a}$ & $16.91 \mathrm{~b}$ & $61.74 \mathrm{a}$ \\
\hline \multicolumn{6}{|l|}{ Seed size $(\mathrm{mm})$} \\
\hline 5.5 & & $10.64 \mathrm{~b}$ & $78.22 \mathrm{a}$ & $17.63 \mathrm{a}$ & $61.54 \mathrm{a}$ \\
\hline 6.5 & & $11.04 \mathrm{a}$ & $77.41 \mathrm{a}$ & $17.66 \mathrm{a}$ & $62.19 \mathrm{a}$ \\
\hline Factor & GL & \multicolumn{4}{|c|}{ Medium square } \\
\hline Blocks & 4 & & & & \\
\hline Furrowers (F) & 1 & $14.45^{* *}$ & $5.94^{\mathrm{ns}}$ & $10.80 *$ & $0.31^{\mathrm{ns}}$ \\
\hline Seed size (S) & 1 & $0.80^{*}$ & $3.28^{\mathrm{ns}}$ & $0.00^{\mathrm{ns}}$ & $2.11^{\mathrm{ns}}$ \\
\hline $\mathrm{F} \times \mathrm{S}$ & 1 & $0.15^{\mathrm{ns}}$ & $0.08^{\mathrm{ns}}$ & $0.76^{\text {ns }}$ & $0.36^{\mathrm{ns}}$ \\
\hline Residue & 12 & & & & \\
\hline CV (\%) & & 3.8 & 2.3 & 6.8 & 4.1 \\
\hline
\end{tabular}

Table 4. Mean values and summary of ANOVA of plant populations per hectare, 30 days after sowing (Pop 30 DAS) and at harvest time (Pop Colh), according to furrow opener types and seed sizes, crop seasons 2014/2015 and 2015/2016.

\begin{tabular}{|c|c|c|c|c|c|}
\hline \multirow{2}{*}{ Treatments } & & Pop 30 DAS & Pop Colh & Pop 30 DAS & Pop Colh \\
\hline & & \multicolumn{2}{|c|}{$2014 / 2015$} & \multicolumn{2}{|c|}{$2015 / 2016$} \\
\hline \multicolumn{6}{|l|}{ Furrowers } \\
\hline Disc & & 138074 & 130370 & 313185 a & 293481 a \\
\hline Shank & & 190518 & 174666 & 292889 a & 263111 a \\
\hline \multicolumn{6}{|l|}{ Seed size $(\mathrm{mm})$} \\
\hline 5.5 & & 173037 & 163851 & 300148 a & 274222 a \\
\hline 6.5 & & 155555 & 141185 & 305926 a & 282370 a \\
\hline Factor & GL & \multicolumn{4}{|c|}{ Medium square } \\
\hline Blocks & 4 & & & & \\
\hline Furrowers (F) & 1 & $13752127901^{* *}$ & $9810766672 * *$ & $2059698968^{\text {ns }}$ & $46118363351^{\text {ns }}$ \\
\hline Seed size (S) & 1 & 1527979248* & $2568828444 *$ & $166909086^{\text {ns }}$ & $331941372^{\text {ns }}$ \\
\hline $\mathrm{F} \times \mathrm{S}$ & 1 & $1426174716^{*}$ & $1826189827^{*}$ & $408345882^{\text {ns }}$ & $242423808^{\text {ns }}$ \\
\hline Residue & 12 & & & & \\
\hline CV (\%) & & 9.8 & 11.2 & 7.1 & 6.6 \\
\hline
\end{tabular}

Table 5. Mean values of the plant population per hectare, 30 days after sowing (Pop 30 DAS) and at harvest time (Pop Colh), according to furrow opener types and seed sizes, crop season 2014/2015.

\begin{tabular}{|c|c|c|c|c|}
\hline \multirow{3}{*}{ Furrowers } & \multicolumn{3}{|c|}{ Pop 30 DAS } & \multirow[t]{2}{*}{ Pop Colh } \\
\hline & \multicolumn{3}{|c|}{ Seed size $(\mathrm{mm})$} & \\
\hline & 5.5 & 6.5 & 5.5 & 6.5 \\
\hline Disc & $138370 \mathrm{Ab}$ & $137778 \mathrm{Ab}$ & $132148 \mathrm{Ab}$ & $128593 \mathrm{Ab}$ \\
\hline Shank & $207704 \mathrm{Aa}$ & $173333 \mathrm{Ba}$ & $195555 \mathrm{Aa}$ & $153778 \mathrm{Ba}$ \\
\hline CV (\%) & \multicolumn{2}{|c|}{9.8} & \multicolumn{2}{|c|}{11.2} \\
\hline
\end{tabular}

For each character, means followed by the same lowercase letters in the column do not differ significantly from each other ac cording to Tukey's test at $5 \%$ error probability

Table 6. Mean values and summary of ANOVA of number of pods per plant (NVP) and number of seeds per pod (NGV), according to furrow opener types and seed sizes, crop seasons 2014/2015 and 2015/2016.

\begin{tabular}{|c|c|c|c|c|c|}
\hline \multirow{2}{*}{\multicolumn{2}{|c|}{ Treatments }} & NVP & NGV & NVP & NGV \\
\hline & & \multicolumn{2}{|c|}{$2014 / 2015$} & \multicolumn{2}{|c|}{$2015 / 2016$} \\
\hline \multicolumn{6}{|l|}{ Furrowers } \\
\hline Disc & & $84.65 \mathrm{a}$ & $2.47 a$ & $37.10 \mathrm{~b}$ & $2.32 \mathrm{a}$ \\
\hline Shank & & $62.97 \mathrm{~b}$ & $2.46 a$ & $43.37 \mathrm{a}$ & $2.33 \mathrm{a}$ \\
\hline \multicolumn{6}{|c|}{ Seed size $(\mathrm{mm})$} \\
\hline 5.5 & & $67.85 b$ & $2.47 \mathrm{a}$ & $40.16 \mathrm{a}$ & $2.33 \mathrm{a}$ \\
\hline 6.5 & & $79.77 \mathrm{a}$ & $2.45 \mathrm{a}$ & $40.31 \mathrm{a}$ & $2.32 \mathrm{a}$ \\
\hline Factor & $\mathrm{GL}$ & \multicolumn{4}{|c|}{ Medium square } \\
\hline Blocks & 4 & & & & \\
\hline Furrowers (F) & 1 & $2350.11^{* *}$ & $0.00^{\mathrm{ns}}$ & $196.56^{* *}$ & $0.00^{\mathrm{ns}}$ \\
\hline Seed size (S) & 1 & $710.43^{* *}$ & $0.00^{\mathrm{ns}}$ & $0.11^{\text {ns }}$ & $0.00^{\mathrm{ns}}$ \\
\hline $\mathrm{F} \times \mathrm{S}$ & 1 & $65.52^{\mathrm{ns}}$ & $0.00^{\mathrm{ns}}$ & $11.70^{\text {ns }}$ & $0.00^{\text {ns }}$ \\
\hline Residue & 12 & & & & \\
\hline CV (\%) & & 9.0 & 1.8 & 8.7 & 2.6 \\
\hline
\end{tabular}

For each character, means followed by the same lowercase letters in the column do not differ significantly from each other according to Tukey's test at $5 \%$ error probability. 
Table 7. Mean values and summary of ANOVA of thousand grain weight (MMG) and productivity (Prod), according to furrow opener types and seed sizes, crop seasons 2014/2015 and 2015/2016.

\begin{tabular}{|c|c|c|c|c|c|}
\hline \multirow{2}{*}{ Treatments } & & MMG & Prod & MMG & Prod \\
\hline & & \multicolumn{2}{|c|}{$2014 / 2015$} & \multicolumn{2}{|c|}{$2015 / 2016$} \\
\hline \multicolumn{6}{|l|}{ Furrowers } \\
\hline Disc & & $155.70 \mathrm{a}$ & $4326.66 \mathrm{~b}$ & $145.48 \mathrm{a}$ & $4063.49 \mathrm{a}$ \\
\hline Shank & & $158.40 \mathrm{a}$ & $4583.02 \mathrm{a}$ & $137.81 \mathrm{~b}$ & $3777.07 \mathrm{~b}$ \\
\hline \multicolumn{6}{|c|}{ Seed size $(\mathrm{mm})$} \\
\hline 5.5 & & $157.45 \mathrm{a}$ & $4475.58 \mathrm{a}$ & $140.53 \mathrm{a}$ & $3824.31 \mathrm{~b}$ \\
\hline 6.5 & & $156.65 \mathrm{a}$ & $4434.10 \mathrm{a}$ & $142.76 \mathrm{a}$ & $4016.25 \mathrm{a}$ \\
\hline Factor & $\mathrm{GL}$ & \multicolumn{4}{|c|}{ Medium square } \\
\hline Blocks & 4 & & & & \\
\hline Furrowers (F) & 1 & $36.42^{\mathrm{ns}}$ & $328602.24 *$ & $293.68 * *$ & $410170.62 * *$ \\
\hline Seed size $(S)$ & 1 & $3.20^{\text {ns }}$ & $8602.12^{\mathrm{ns}}$ & $24.99^{\text {ns }}$ & $184208.65^{*}$ \\
\hline $\mathrm{F} \times \mathrm{S}$ & 1 & $0.00^{\text {ns }}$ & $67924.17^{\text {ns }}$ & $0.40^{\mathrm{ns}}$ & $19070.25^{\mathrm{ns}}$ \\
\hline Residue & 12 & & & & \\
\hline CV (\%) & & 2.1 & 4.2 & 2.8 & 4.6 \\
\hline
\end{tabular}

For each character, means followed by the same lowercase letters in the column do not differ significantly from each other according to Tukey's test at $5 \%$ error probability.

furrow opener, which resulted in a greater thousand grain weight.

Camozzato et al. (2009) evaluated three soybean cultivars and two seed sizes (small - $5.5 \mathrm{~mm}$, and large $-6.5 \mathrm{~mm}$ ), and observed no difference for the thousand grain weight on the basis of seed size, which is in line with the findings of Avila et al. (2008), where tested seeds with 5.5 and $7.0 \mathrm{~mm}$. Plants grown from smaller seeds may compensate their lower initial growth at later stages of the crop cycle, ensuring similar grain production to plants from larger seeds (Avila et al., 2008).

Regarding seed size, a difference was only observed in the second season, in which higher productivity was achieved from larger seeds. Padua et al. (2010) evaluated the influence of the size of soy seeds $(4.0,5.0$ and $6.0 \mathrm{~mm}$ sieves) in three cultivars and found that there was a direct relationship between seed size and productivity of plants, by which larger seeds generate more productivity.

\section{Materials and methods}

\section{Location of the experiment}

The experiment was conducted in Pato Branco, Paraná Brazil (Fig 2), in two crop seasons (2014/2015 and 2015/2016), in a typical distroferric red nitisol (Soil Survey Staff, 2014) with very clayey texture. Chemical soil features, in the layer at a depth of $0.0-0.10 \mathrm{~m}$, were: $\mathrm{MO}_{\text {(Walkley-Black) }}=$ $20.10 \mathrm{gdm}^{-3} ; \mathrm{P}_{(\text {Mehlich I) }}=15.70 \mathrm{mgdm}^{-3} ; \mathrm{K}_{(\text {Mehlich I) }}=0.30$ $\mathrm{cmol}_{\mathrm{c}} \mathrm{dm}^{-3} ; \mathrm{Cu}=3.89 \mathrm{mgdm}^{-3} ; \mathrm{Fe}=42.00 \mathrm{mgdm}^{-3} ; \mathrm{Zn}=2.04$ $\mathrm{mgdm}^{-3} ; \mathrm{Mn}: 51.73 \mathrm{mgdm}^{-3} ; \mathrm{pH}_{(\mathrm{CaCl} 2)}=4.60$; Índice SMP: 5.70; $\mathrm{Al}_{(1 \mathrm{M} \mathrm{KCl})}^{+3}=0.32 \mathrm{cmol}_{\mathrm{C}} \mathrm{dm}^{-3} ; \mathrm{H}+\mathrm{Al}=6.21 \mathrm{cmol}_{\mathrm{C}} \mathrm{dm}^{-3}$; $\mathrm{Ca}^{2+}{ }_{(1 \mathrm{M} \mathrm{KCl})}=4.50 \mathrm{cmol}_{\mathrm{C}} \mathrm{dm}^{-3} ; \mathrm{Mg}=2.70 \mathrm{cmol}_{\mathrm{C}} \mathrm{dm}^{-3} ; \mathrm{SB}: 7.50$ $\mathrm{cmol}_{\mathrm{C}} \mathrm{dm}^{-3} ; \mathrm{V}=54.70 \%$ and aluminum saturation $=4.09 \%$.

The climate is Cfa humid subtropical, according to Köppen, and the mean annual rainfall is $1,800 \mathrm{~mm}$. Figure 1 shows meteorological data observed during the evaluation period.

\section{Experimental design}

A randomized block design in factorial structure $(2 \times 2)$, with five replications was applied. Treatments consisted of the combination of two seed sizes (large, $6.5 \mathrm{~mm}$, and small, 5.5 $\mathrm{mm}$ in diameter) and two types of furrow opener (shank and double disc). The area was divided into five blocks, totally twenty experimental units. Each unit had a total area of 37.0 $\mathrm{m}^{2}(3.7 \times 10 \mathrm{~m})$ and a useful area of $6.75 \mathrm{~m}^{2}$. Blocks were separated by a space of $10.00 \mathrm{~m}$, which was used for maneuvering and stabilizing the working speed of the tractor-seeder set.

\section{Characterization of the seeds}

The seeds used in both seasons were certified soybean seed (C1) from the Nidera NS 4823 RR cultivar, produced in the Pato Branco region of the state of Paraná. Seeds were sown on $10 / 13 / 2014$, for the $2014 / 2015$ crop season, and on $10 / 19 / 2015$ for the $2015 / 2016$ season, at a rate of 15.3 seeds per linear meter, aiming at resulting in a final stand of 300,000 plants ha- ${ }^{-1}$. For basic fertilization, $350 \mathrm{~kg} \mathrm{ha}^{-1}$ of the 05-20-20 formulation was applied in the planting line, and phytosanitary treatments were performed as recommended for soybean cultivation and experiment monitoring.

\section{Evaluated parameters}

The depth of seed deposition in each experimental unit was determined by sampling the depth of twenty seeds. A wooden profilometer was used to assess the mobilized soil area, with vertical strips graduated in centimeters and arranged transversely to the sowing row at $0.02 \mathrm{~m}$ intervals. Measurements were taken from the three central planting lines, obtaining the natural and final surface profiles of the furrow.

The emergence speed index (IVE) was assessed in the useful area of each experimental unit and the seedlings count was carried out daily, until the number of emerged seedlings became constant. Each plant was considered emerged from the moment it emerged from the soil and could be seen with the naked eye at any angle, in accordance with the methodology proposed by Maguire (1962).

The plant population was determined by counting the plants in the useful area of each experimental unit, at two crop development stages; 30 days after sowing and at harvest time. The final figure was adjusted by the number of 
plants per hectare. Plant heights were assessed at the same time as counting of the plant population. Ten plants were measured in each experimental unit.

Once the soybean reached harvest maturity, a manual harvest was carried out and threshing was performed using a stationary threshing machine. Yield was estimated by extrapolating to one hectare, the beans harvested from the useful area and adjusting the moisture to $12 \%$.

At the same time, twenty plants per plot were randomly cropped to assess the number of pods per plant and grains per pod. The thousand grain weight was calculated in accordance with the Rules for Seed Analysis (Brazil, 2009).

\section{Statistical analysis}

Data were submitted to analysis of variance to evaluate the effects of the factors and their interactions, using the Genes statistical software (Cruz, 2013). When the value of the $F$ test was significant at $5 \%$ probability, Tukey's test was applied for comparison of the means. All data were submitted to Lilliefors test $(p \leq 0.05)$ to verify the homogeneity of variances.

\section{Conclusion}

The shank-type furrow opener mobilized a greater area of soil and reached greater depth of seed deposition. The shank-type furrow opener provided greater plant population, compared to the double-disc type, under a condition of lack of rainfall. The disc-type furrow opener contributed positively to plant emergence speed, higher plant height 30 days after sowing, higher thousand grain weight and greater productivity, when rainfall was regular. Smaller seeds generated plants with lower height, 30 days after sowing, and a smaller number of pods per plant, under water-deficit conditions. Larger seeds resulted in higher productivity under normal rainfall regime.

\section{Acknowledgments}

The authors would like to thank the National Council for Scientific and Technological Development (CNPq), the Coordination for the Improvement of Higher Education Personnel (CAPES) and the Federal University of Technology of Paraná (UTFPR) for funding this research.

\section{References}

Andrade RV, Andreoli C, Borba CS, Azevedo JT, Netto DAM, Oliveira AC (1997) Efeito da forma e do tamanho da semente no desempenho no campo de dois genótipos de milho. Rev Bras Sementes. 19: 62-65.

Aratani RG, Maria IC, Castro OM, Filho AP, Duarte AP, Kanthack RAD (2006) Desempenho de semeadorasadubadoras de soja em latossolo vermelho muito argiloso com palha intacta de milho. Rev Bras Eng Agr Amb. 10: 517-522.

Ávila W, Perin A, Guareschi RF, Gazolla PR (2008) Influência do tamanho da semente na produtividade de variedades de soja. Agrarian. 1: 83-89.

Barbosa CZR, Smiderle OJ, Alves JMA, Vilarinho AA, Sediyama T (2010) Qualidade de sementes de soja BRS Tracajá, colhidas em Roraima em função do tamanho no armazenamento. Rev Cienc Agron. 41: 73-80.

BRASIL. Ministério da Agricultura, Pecuária e Abastecimento (2009) Regras para análise de sementes. Brasília, Brasil.

Camozzato VA, Peske ST, Possenti JC, Mendes AS (2009) Desempenho de cultivares de soja em função do tamanho das sementes. Rev Bras Sementes. 31: 288-292.

Cruz CD (2013) Programa genes (versão windows): aplicativo computacional em genética e estatística. Viçosa, Brasil.

Dan LGM, Dan HA, Barroso ALL, Braccini AL (2010) Qualidade fisiológica de sementes de soja tratadas com inseticidas sob efeito do armazenamento. Rev Bras Sementes. 32: 131-139.

Francetto TR, Alonço AS, Bellé MP, Franck CJ, Carpes DP (2015) Comportamento operacional de associações entre sulcadores e discos de corte para sistema de semeadura direta. Eng Agric. 35: 542-554.

IAPAR - Instituto Agronômico do Paraná (2016) Agrometeorologia. Disponível em: <http://www.iapar.br >. Accessed in June 2016.

Koakoski A, Souza CMA, Rafull LZL, Souza LCF, Reis EF (2007) Desempenho de semeadora-adubadora utilizando-se dois mecanismos rompedores e três pressões da roda compactadora. Pesqui Agropecu Bras. 42: 725-731.

Levien R, Furlani CEA, Gamero CA, Conte O, Cavichioli FA (2011) Semeadura direta de milho com dois tipos de sulcadores de adubo, em nível e no sentido do declive do terreno. Cienc Rural. 41: 1003-1010.

Maguire JD (1962) Speed of germination-aid in selection and evaluation for seedling emergence and vigor. Crop Sci. 2: 176-177.

Marcos Filho J (2013) Importância do potencial fisiológico da semente de soja. Abrates. 23: 21-24.

Morando R, Silva AO, Carvalho LC, Pinheiro MPMA (2014) Déficit hídrico: efeito sobre a cultura da soja. Journal of Agronomic Sciences. 3: 114-129.

Moterle LM, Santos RF, Braccini AL, Scapim CA, Lana MC (2009) Influência da adubação com fósforo e potássio na emergência das plântulas e produtividade da cultura da soja. Rev Cienc Agron. 40: 256-265.

Pádua GP, Zito RK, Arantes NE, Neto JBF (2010) Influência do tamanho da semente na qualidade fisiológica e na produtividade da cultura da soja. Rev Bras Sementes. 32: 9-16.

Pereira WA, Pereira SMA, Dias DCFS (2013) Influence of seed size and water restriction on germination of soybean seeds and on early development of seedlings. J Seed Sci. 35: 316322.

Reis EF, Schaefer CEGR, Fernandes HC, Naime JM, Araújo EF (2006) Densidade do solo no ambiente solo-semente e velocidade de emergência em sistema de semeadura de milho. Rev Bras Cienc Solo. 30: 777-785.

Soil Survey Staff. Keys to soil taxonomy (2014) 12. ed. Washington: U. S. Department of Agriculture. Natural Resources Conservation Service, 372p

Tourino MCC, Rezende PM, Salvador N (2002) Espaçamento, densidade e uniformidade de semeadura na produtividade e características agronômicas da soja. Pesqui Agropecu Bras. 37: 1071-1077.

Vazquez GH, Carvalho NM, Borba MMZ (2008) Redução na população de plantas sobre a produtividade e a qualidade fisiológica da semente da soja. Rev Bras Sementes. 30: 0111. 